\title{
Do they not seem normal? Indonesian teachers reading gender biased folktales
}

\author{
E. Eliyanah* \& A. Zahro \\ Universitas Negeri Malang, Malang, Indonesia
}

\begin{abstract}
Gender responsive education needs gender sensitive teachers as they will be able to provide teaching and learning activities that critically engage with the social construction of genders and address gender biases. Our research examines teachers' sensitivity towards gender biases in teaching materials, in this case, in the written version of Indonesian folktales. We asked 24 teachers from Medan, Malang, and Ambon to fill out a reception questionnaire on the characters and character development. Our analysis on the teachers' responses shows that these teachers tend to overlook gender biases in the sampled folktale. They barely noticed the biased characterization and treatment of the male and female protagonists. In doing so, teachers risk sustaining the normalized gender biases and maintaining practices. This finding implies the pressing need for awareness and gender training among teachers in Indonesia to ensure the implementation of gender responsive education.
\end{abstract}

Keywords: folktale, gender bias, reading, gender responsive, education

\section{INTRODUCTION}

Gender responsive education needs gender sensitive teachers. This is because teachers have great potential in inspiring and empowering their students (Frei \& Leowinata 2014; UNESCO 2017). Thus, in order to instill values of gender equality in students, the need for gender sensitive teachers is unquestionable. Gender sensitive teachers will be able to provide teaching and learning activities which critically engage with the social construction of genders and address gender biases. The opposite generally, whether intentionally or unintentionally, will likely maintain normalized gender biases. Thus, teachers should have the capacity to integrate gender perspectives into their teaching (The Global Partnership for Education and UNGEI 2016).

Our research examines teachers' sensitivity towards gender biases in teaching materials, in this case, in the written version of Indonesian folktales. We involved 24 teachers from Medan, Malang and Ambon in filling out a reception questionnaire. Our analysis of the teachers' responses shows that these teachers tend to overlook gender biases in the sampled folklore. Regardless of the teachers' gender, age, and cultural origin, they barely noticed the biased characterization and treatment of the male and female protagonists. In doing so, teachers risk sustaining the normalized gender biases, which tend to be disadvantageous to women, and maintaining practices which tend to discriminate against women. This finding implies the pressing need for awareness and gender training among teachers in Indonesia to ensure the implementation of gender responsive education.

\footnotetext{
*Corresponding author: evi.eliyanah.fs@um.ac.id
} 
Table 1. Research participants.

\begin{tabular}{llcc}
\hline Region & Gender & Age & Total \\
\hline Medan & Female & $<35$ & 5 \\
& & $<45$ & 2 \\
& & $>45$ & 1 \\
& Male & $<35$ & 2 \\
& & $<45$ & 0 \\
Malang & Female & $<45$ & 0 \\
& & $<35$ & 3 \\
& & $>45$ & 0 \\
& Male & $<35$ & 3 \\
& & $<45$ & 2 \\
Ambon & & $>45$ & 2 \\
& Female & $<35$ & 0 \\
& & $<45$ & 0 \\
& & $>45$ & 0 \\
Total & Male & $<35$ & 2 \\
& & $>45$ & 1 \\
& & & 1 \\
\hline
\end{tabular}

\section{METHODS}

This research is part of a larger research project on the representation of gender in the written version of Indonesian folktales. Our findings on the representations of female heirs in the contemporary written version of Indonesian folktales show that despite the dynamic nature of folktales, the characterizations of female heirs, or princesses, are still anchored in their looks and in a cult of domesticity (Zahro et al. 2020). In this paper, we would like to report our findings on how elementary school teachers in Indonesia, who are part of the target users of the written folklore, receive the stories. Data was collected through distribution of a questionnaire. The collected data was then analyzed using discourse analysis.

The stories that we studied are intended for young readers. Such intentions are written in the cover page of each story book. Thus, we assume that elementary school teachers have important roles in promoting the books to the intended readers, including using the books as part of their teaching materials. The books are electronically published and available for free download from the website of Badan Pengembangan dan Pembinaan Bahasa (Institute for Language Development and Preservation), from the Ministry of Education and Culture. For this reception study, we randomly selected Kisah Dewi Samboja: Cerita Rakyat dari Jawa Barat (The Story of Princess Samboja: A Folktale from West Java), written by Nia Kurnia (2016), to be read by our participants. The story revolves around the trials and tribulation of Dewi Samboja (Princess Samboja), a female heir to the Galuh Kingdom in West Java. The story is intended for readers in years 4, 5, and 6, or roughly for 10- to 12-year-old readers. The story was part of representation study mentioned earlier. We argue that the story, in addition to other stories on the same website, is biased against female characters.

We asked 24 teachers from Medan, Malang, and Ambon to participate in this reception research. The three cities were selected as they represent the western, the central, and the eastern parts of Indonesia respectively. First, we supplied the teachers with the selected story, and we also showed them the website where the story can be accessed publicly. Afterward, we asked them to fill out a questionnaire containing ten questions. The questionnaire contains ten open-ended questions which revolve around characterization and character development. The open-ended questions were chosen in order to provide participants with room for more elaborate critical engagement. 
The answers collected from the questionnaire were then analyzed using discourse analysis. We identified key words from answers to each question. We also gathered information on the background of each participant, including their age, gender, location of their workplace. In addition, we also study the contemporary socio-cultural contexts. These pieces of information are important to put the reception in context as we believe that discourse is both constitutive and constituted (Jorgensen \& Phillips 2002). Afterwards, we drew patterns and themes. Lastly, we reviewed our results and drew a conclusion. We discuss our findings below.

\section{RESULTS AND DISCUSSION}

Our analysis shows that these teachers tend to overlook gender biases in the sampled folktale. Regardless of the teachers' gender, age, and cultural origin, they barely noticed the biased characterization and treatment of the male and female protagonists. In doing so, teachers risk sustaining the normalized gender biases, which tend to be disadvantageous to women, and maintaining practices which tend to discriminate against women.

In the first two questions, the research participants were to write four impressions on the character of Dewi Samboja and Pangeran Anggalarang (Prince Anggalarang), the female and male protagonists of the story respectively. In their impressions of Dewi Samboja, we found twenty keywords, with kind, pretty, and obedient to her parents being the most mentioned. As to the impressions of Pangeran Anggalarang, the traits which were most mentioned include courageous/brave (both in the sense of fighting his enemies in war and facing his future father-in-law), obedient to the elderly, and handsome.

The stereotypical feminine and masculine traits in the readers' perception are further reinforced in their answers for the third and fourth questions on why the female and male characters choose their life partner. The third question asks the participants reception on the reason Anggalarang chooses Samboja as his future wife. Among the six keywords found, the top three include Samboja's kindness, beauty, and compassion. In question where participants were asked about their perception on why Dewi Samboja accepted Pangeran Anggalarang's marriage proposal, there are ten keywords found, the topmost answers being related to parental approval, in Anggaralang's courage and bravery in facing Samboja's father to get his approval (19 mentions). The second most popular perception is Anggalarang's being a handsome prince and kind with three mentions each.

The above findings show that the stereotypical characterizations of ideal feminine and masculine traits leave strong imprints in the readers' minds. Being born and raised in Indonesia, we can claim that ideal femininity is often characterized by beauty and kind-heartedness. While beauty is undoubtedly feminine, kind-heartedness may sound neutral. Indeed, male characters can be kind too. Yet, such characterization is not central to ideal masculinity in the story, unlike bravery and courage. Likewise, several research participants also mention Dewi Samboja being brave and able to fight, but these traits are not the common impression readers get from the story. Despite the possibility for more critical engagement in answering the reception questions, none of the research participants challenge the stereotypical characterization, which further validates our argument that they are mostly lacking sensitivity towards biased characterization of gender in teaching materials. These findings thus also reinforce our argument (Zahro et al. 2020) that physical beauty remains the anchor in the characterization of female protagonists, and bravery in that of male protagonist, in the written versions of Indonesian folktales published after 2000, where gender equality has been the subject of numerous open public debates, unlike during the authoritarian regime (Robinson 2006).

The fifth, sixth, and seventh questions are related to readers' expectation on Samboja, a female heir to a kingdom. These questions include what skills and training the readers expect Samboja to have learned; whether the story indicates that Samboja has learned those skills; and what they expect Samboja to do with the skills. We found thirty keywords, and the top five include compassion, putting people's welfare first, martial arts, wisdom and strategic thinking. The participants almost unanimously agreed that Samboja has been trained in the mentioned skills. Then, participants 
expressed that they expected Samboja to continue learning and training, stay true to herself, and get married to a prince; other expectation keywords received a lower number of mentions.

The answers to the set of three questions show that readers support Samboja being a female heir and thus must possess strong leadership skills. Female beauty is not mentioned at all in these questions. However, bias emerges in the further expectation (question 7) which suggest that some of the participants believed that being a female heir, Samboja still needs to be married strategically to a prince who will support her in ruling her kingdom.

The eighth and ninth questions explore the participants' responses towards two incidents, which we deemed highly gendered: Anggalarang's action to save Samboja from the pirates, and Samboja's marriage proposal to Patih Sawunggaling upon the death of her first husband, Anggalarang. In answering the eighth question, the research participants tended to normalize or even valorize Anggalarang's bravery and sacrifice - calling the act as a husband's sacrifice for the sake of his beloved (13 mentions), a husband's responsibility (10 mentions), and a husband's duty to protect his wife. The last two can be merged since the sense we gleaned from the answers is the same - it is a husband's responsibility to protect his wife. The open-ended nature of the question only inspired one participant to question Samboja's martial arts skills despite her being trained. Furthermore, in answering question nine, research participants tend to normalize Samboja's strategic marriage to Patih Sawung Galing, his deceased husband's former confidante, because Samboja needs a strong male ally to win her throne back; Samboja needs a man to protect her; and Samboja needs to move on with her life with a new partner after the death of her husband.

The responses to the two questions above clearly indicate internalized patriarchy. The masculine act of sacrificing oneself for his beloved or for his nation is commonly found in other tales of princes and princess around the world. In Western folklore tradition, for instance, many princesses are waiting to be saved by a prince charming in order to be able to live happily ever after. Such narrative normalizes women's helplessness in the face of danger and men's chivalry to offer protection and sacrifice. Moreover, the perception of feminine normalized helplessness is further reinforced in the participants' response towards question nine. These answers imply the participants' perception on women being less capable leaders, who can only be strong if accompanied by strong male allies or husbands.

The last question is a conclusion question. We asked the participants' conclusion on what it took to be a female heir. We found 27 keywords in the collected answers, with the top five being putting the people's welfare ahead of hers, being kind, loving her people, being wise, as well as having compassion and beauty. These answers show that the participants seem to agree that it takes particular soft skills to succeed in becoming a great female leader. Yet, they seem to not leave beauty in the ideal character trait of a female leader.

\section{CONCLUSION}

Overall, the findings not only reinforce our argument that the story is gender biased, but also reveal that Indonesian teachers who are expected to be more critical in engaging with such stories still normalize the stereotypical characterization of gender in teaching materials. They barely see the biases, which tend to place women as the weaker sex. Such a tenet is further reinforced in their perception of female leaders requiring protection from male allies, who are likely their husbands. In short, most of the teachers in this study perceive it as normal for a female leader to be pretty, strong, smart, but still be physically and skillfully weak compared to men; thus, she still need a man's protection in order to rule and make her country strong.

The implication of our findings is that awareness raising campaigns and activities are still needed. Such ideas can be carried out in the forms of trainings and workshops on gender responsive curriculum. Teachers at all levels must be sensitive of gender issues and able to address responsively to them in their teaching. Secondly, teaching materials are expected to be more gender responsive in order to cultivate gender awareness and nurture responsiveness in education. 
Future researchers can benefit from our research and explore teachers' perceptions further on how gender should be represented in teaching materials and curriculum in general. Our early research design was to conduct focus group discussions with teachers in the abovementioned cities. Yet, the design must be modified as the Covid-19 pandemic hit almost every city in Indonesia. As domestic travel restrictions were tightened, we decided to distribute questionnaires to the targeted participants, instead. We did not follow up with a cloud meeting due to time constraints. Thus, future research can pick up from where we left off.

\section{REFERENCES}

Frei, S., \& Leowinata, S. 2014. Gender Mainstreaming Toolkit for Teachers and Teacher Educators. British Columbia: Commonwealth of Learning.

Jørgensen, M., \& Phillips, L. 2002. Discourse Analysis as Theory and Method. London, Thousand Oaks and New Delhi: SAGE Publications.

Kurnia, N. 2016. Kisah Dewi Samboja: Cerita Rakyat dari Jawa Barat. Jakarta: Badan Pengembangan dan Pembinaan Bahasa.

Robinson, K. 2006. Islamic Influences on Indonesian Feminism. Social Analysis: The International Journal of Anthropology, 50(1), 171-177.

The Global Partnership for Education and UNGEI. 2016. Guidance for Developing Gender-Responsive Education Sector Plans. Washington: The Global Partnership for Education.

UNESCO. 2017. Gender-Responsive Classrooms Need Gender-Sensitive Teachers. 29 May. Retrieved from https://bangkok.unesco.org/content/gender-responsive-classrooms-need-gender-sensitive-teachers

Zahro, A., Eliyanah, E., \& Ahmadi, A. 2018. Women and the Indonesian Folktales: Gender Perspective. International Journal of Humanities and Cultural Studies, 7(2), 89-99. 